\title{
Cystic Fibrosis Genotyping by Direct PCR Analysis of Guthrie Blood Spots
}

\author{
S. Raskin, ${ }^{1,3}$ J.A. Phillips III, ${ }^{1}$ G. Kaplan, ${ }^{2}$ M. McClure, ${ }^{2}$ and C. Vnencak-Jones ${ }^{1}$
}

\author{
${ }^{1}$ Division of Genetics, Department of Pediatrics, Vanderbilt Univeristy, Nashville, Tennessee 37232-2578; ${ }^{2}$ DNA Diagnostic \\ Laboratory, Vivigen, Inc., Santa Fe, New Mexico; ${ }^{3}$ Universidade Federal do Parana, Curitiba, Parana, Brazil 80410
}

In the United States the most common cystic fibrosis (CF) alleles known are F508, G551D, G542X, R553X, and N1303K. These mutations comprise $\sim \mathbf{8 5} \%$ of U.S. CF alleles, and their detection along with analysis of XV-2C and $\mathrm{KM}-19$ restriction fragment length polymorphisms (RFLPs) can enable the determination of CF status. To facilitate studies for determining CF carrier status, we developed methods to detect each of these mutations and RFLPs by direct PCR amplification of dried blood spots collected on newborn screening (Guthrie) cards. Following collection, samples were protected from contamination by individual plastic bags. One- $\mathrm{mm}^{2}$ segments of filter paper were added directly to $100-\mu l$ PCR reactions containing $1 / 16 \mathrm{~mm}$ spermidine. Three initial cycles at $96^{\circ} \mathrm{C}$, then $55^{\circ} \mathrm{C}$, for $3 \mathrm{~min}$ were performed to free DNA and minimize inhibition by other related materials. Next, 1 unit of Taq polymerase was added and a 2-min extension was carried out at $72^{\circ} \mathrm{C}$, followed by $33 \mathrm{am}$ plification cycles using denaturing, annealing, and extension temperatures and times optimal for each primer set. Then, $35 \mu \mathrm{l}$ of each reaction was run on $8 \%$ acrylamide gels directly or $1 \%$ agarose gels following digestion; genotypes were inferred by ethidlum bromide staining of gels. Guthrie blood spots of 250 CF probands and their parents were screened and the frequencies of all five mutations as well as the XV-2C KM-19 RFLP haplotypes were determined. Our data indicate: (1) direct PCR amplification provides a simple, rapid, and inexpensive method to de- termine CF genotypes directly from dried blood spots and (2) these methods provide special advantages regarding ease and convenience of sample collection, shipment, analysis, and storage

D ried blood spot technology facilitated the historical development of neonatal screening programs. The recent identification of the most common cystic fibrosis (CF) mutation, the deletion of the phenylalanine codon at position 508 (F508) in the cystic fibrosis transmembrane conductance regulator (CFTR) gene, has allowed rapid molecular genetic analysis of CF patients. With the continuing characterization of new mutations within the CFTR gene, there will be a demand to identify simultaneously carriers of the most prevalent mutations. In the United States, the most common CF alleles are F508, G551D, G542X, R553X, and N1303K. These mutations comprise $85 \%$ of U.S. CF alleles, and their identification combined with analysis of XV-2C and KM-19 RFLPs can enable determination of CF status. We developed methods to detect directly each of these mutations and RFLPs by direct PCR amplification of a small piece of a single dried blood spot collected on newborn screening cards. These methods are rapid and accurate and facilitate sample collection, shipment, and storage.

\section{METHODS}

Following collection, samples were protected from contamination by placing them in individual plastic bags. A small piece $\left(1 \mathrm{~mm}^{2}\right)$ was cut from each filter paper blood spot and added directly to a $100-\mu l$ PCR reaction containing $1 / 16 \mathrm{~mm}$ spermidine; $1 \mathrm{~mm}$ of each oligonucleotide primer flanking the exon or intron relevant for each mutation or polymorphism; $10 \mathrm{~mm}$ Tris (pH 8.0); $50 \mathrm{~mm} \mathrm{KCl}$; $1.5 \mathrm{mM} \mathrm{MgCl}_{2} ; 0.001 \%$ gelatin; and 200 $\mathrm{mm}$ of each deoxynucleotide phosphate. ${ }^{(7)}$ Instead of heating the samples 6 min at $94^{\circ} \mathrm{C}$ as usual for genomic DNA templates, the whole PCR reaction was heated for $3 \mathrm{~min}$ at $96^{\circ} \mathrm{C}$ and then cooled for $3 \mathrm{~min}$ at $55^{\circ} \mathrm{C}$. This two-step incubation was repeated three times to free DNA and minimize inhibition by released proteins and heavy metals. ${ }^{(8)}$ Next; 1 unit of Taq polymerase was added and a 2-min extension was done at $72^{\circ} \mathrm{C}$ followed by 33 amplification cycles using denaturing, annealing, and extension temperatures and times optimal for each primer set. ${ }^{(3-6,7,8)}$ Upon completion, a 10 -min extension period was done at $72^{\circ} \mathrm{C}$ and the products were cooled on ice. Next, $35 \mu$ l of each reaction mixture were run directly on nondenaturing polyacrylamide gels in $1 \times$ TBE (Tris-borate-EDTA, pH 8.0) for $1 \mathrm{hr}$ at $100 \mathrm{mV}$ and $2 \mathrm{hr}$ at $300 \mathrm{mV}$, directly (F508), or in 1\% Seakem Agarose (FMC) following restriction endonuclease digestion (G551D, R553X, KM19, and XV2C). Genotypes were inferred following ethidium bromide staining of gels and exposure to UV light. G542X and N1303K were detected by allele-specific hybridization techniques, following standard protocols. ${ }^{(5,6)}$ Guthrie blood spots of $250 \mathrm{CF}$ probands and their parents were screened, and the frequencies of all five mutations as well as the XV2C/ KM19 RFLP haplotypes were determined. 


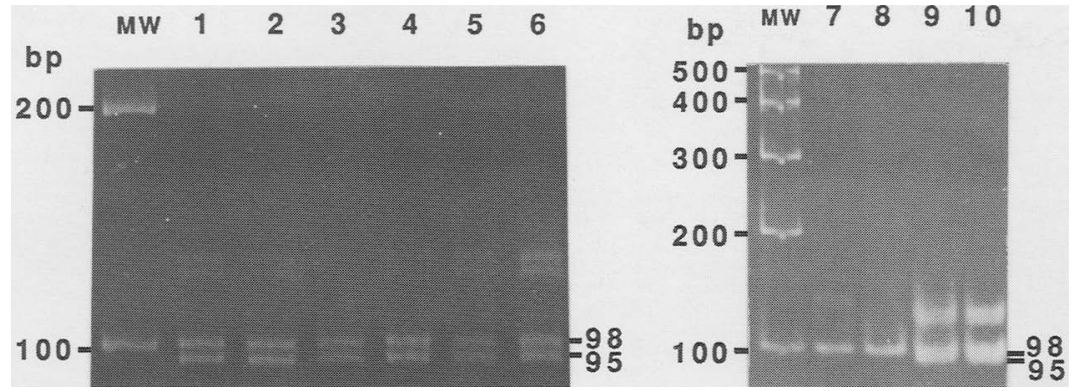

FIGURE 1 Factors influencing PCR reaction yields. The effect of varying cycle number is shown in lanes 1 and 2 at 30 and 33 cycles, respectively. The utility of spermidine addition is seen in lanes 3 and 4 without and with $1 / 16 \mathrm{~mm}$ spermidine, respectively. Effect of varying the initial denaturation condition is shown in lanes 5 and 6 at $94^{\circ} \mathrm{C}$ for 6 min versus $96^{\circ} \mathrm{C} / 55^{\circ} \mathrm{C}$ for $3 \mathrm{~min}$ $\times 3$. The utility of adding Chelex is shown in lanes 7 and 9 (without) versus 8 and 10 (with $5 \%$ suspension of Chelex).

\section{RESULTS}

We have derived conditions that enable specific and reproducible amplification of segments of the CFTR gene that contain five different mutations and two RFLPs. These conditions included (1) using three initial denaturing/annealing cycles of $96^{\circ} \mathrm{C}$ and $55^{\circ} \mathrm{C}$ and adding the enzyme after the incubation step; (2) adding spermidine or Chelex to the PCR amplification reactions; and (3) increasing the number of PCR cycles (see Fig. 1).

Conditions designed to optimize the yield were used to amplify segments of the CFTR gene that contain the F508, G551D, R553X, G542X, and N1303K mutations as well as as the KM19 and XV2C RFLPs (see Figs. 2-5). Analysis of 750 blood spot samples from $250 \mathrm{CF}$ probands and their parents were done. The yields of PCR amplification products from filter paper-derived and isolated genomic DNA were very similar and no dis-

crepancies in genotypes were noted among the 250 patient samples analyzed from both types of templates.

\section{DISCUSSION}

The use of dried blood spots for CF analysis has been previously reported by other investigators. ${ }^{(9-12)}$ The microextraction procedure previously described $^{(9,10)}$ is personnel intensive and therefore would be a costly component of any high-volume DNA diagnostic program based on dried blood spots. Nelson et al. $^{(11)}$ described a procedure that incorporates the need for incubation and boiling the samples, which is time-consuming and may lead to contamination. In our hands, we could not get the same specificity and sensitivity compared to our method. The procedure described by Schwartz et al. for the phenylketonuria gene $^{(12)}$ used a constant heating of the

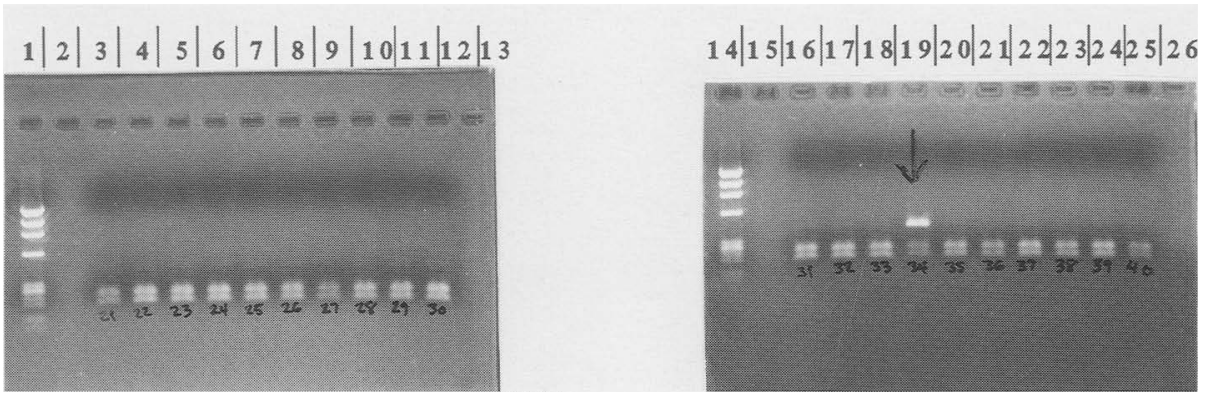

FIGURE 2 Agarose gel electrophoresis of patient samples assayed for G551D and R553X mutations. (Lanes 1 and 14) $\phi X 174 /$ HaeIII molecular weight markers; (lanes 2-12 and 16-25) patient samples digested with HincII. The larger, uncut fragment in lane 19 may correspond to the G551D or R553X mutations. This sample was subsequently digested with $\mathrm{MboI}$ and found to be heterozygous for the G551D mutation; the rest of the samples are homozygous for the normal allele. Lane 13 is a negative control (no DNA). sample for $7 \mathrm{~min}$ at $97^{\circ} \mathrm{C}$ and in our hands gave a reliable yield only for amplification of small PCR fragments, which would be useful for the detection of F508 (98 bp) but not for the other mutations and polymorphisms. Using our protocol, we were able to amplify fragments as large as $2000 \mathrm{bp}$ (data not shown) starting from a small piece of filter paper.

We have developed a method for detecting five CFTR gene mutations and two RFLPs from a single spot on a Guthrie card (Figs. 1-5). A total of 750 samples were evaluated with this optimum protocol and our results indicate that PCR reaction yields can be increased by the use of three initial denaturing/annealing cycles of $96^{\circ} \mathrm{C}$ and $55^{\circ} \mathrm{C}$ and adding the enzyme after the incubation step, addition of spermidine or Chelex to the PCR amplification reactions, and increasing the number of PCR cycles. Two advantages of this method are that it: (1) eliminates the need for tedious and time-consuming methods for extracting DNA from individual blood spots, and (2) increases the number of potential mutations that can be determined from a single card. Our results demonstrate that direct PCR amplification from Guthrie blood spots can provide a rapid, simple, and inexpensive method to screen directly for the presence of $85 \%$ of CF alleles in the United States and to estimate the carrier status for the remaining $15 \%$ of CF alleles. On the basis of the size of the average blood spot on a Guthrie card, more than 25 alleles of CFTR could potentially be screened from a single blood spot. Thus, this method coupled with multiplex CF mutation screening methods theoretically should enable numerous mutations to be detected on a single lane of an acrylamide gel, starting from a small piece of a single dried blood spot, without using radioactive isotopes.

The efficiency and yield of PCR amplification using filter paper is increased by alternating heating and cooling steps. ${ }^{(2)}$ A single longer heating incubation or different times and temperatures of the heating-cooling cycle resulted in poor amplification. Adding the enzyme immediately after the incubation step prevents pre-PCR mispriming and primer dimerization and improves the amplification of genes that occur in low copy number. ${ }^{(13)}$ Adding larger amounts of filter paper was detrimental to the PCR reaction, probably because of the 


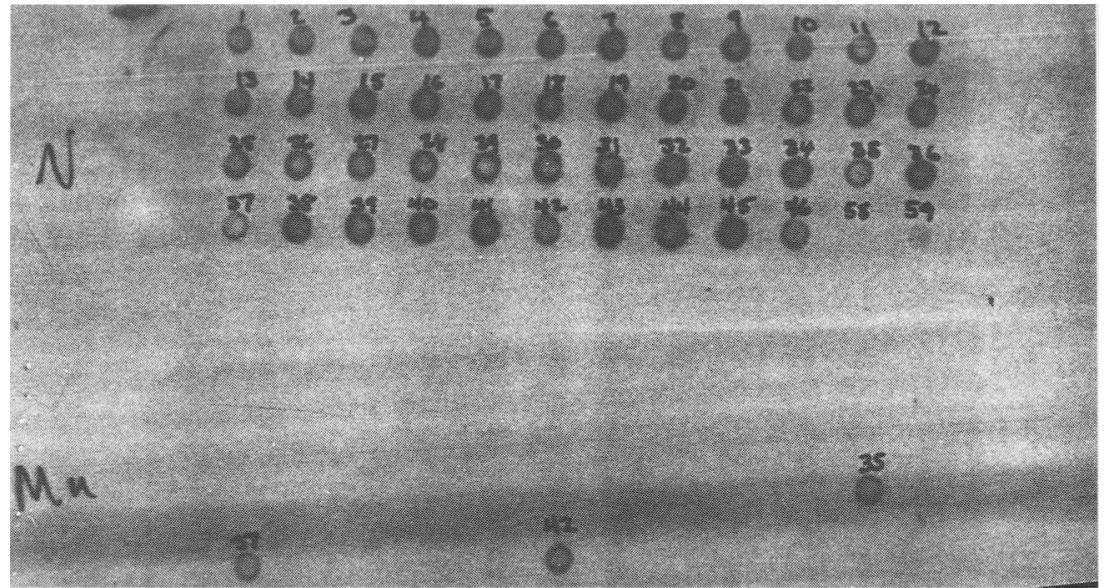

FIGURE 3 Slot-blot hybridization analysis of PCR-amplified products using allele-specific oligonucleotide probes for the G542X mutation. Patient samples numbered 35, 37, and 42 are heterozygous for the mutant allele whereas the remainder are homozygous for the normal allele.

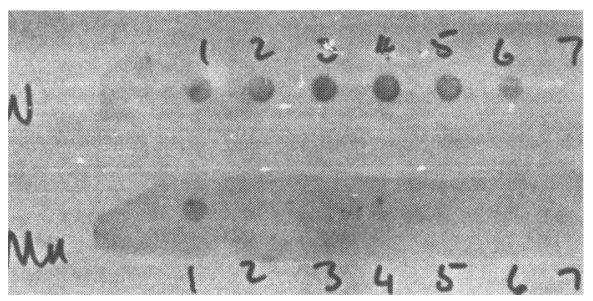

FIGURE 4 Slot-blot hybridization analysis of PCR-amplified products using allele-specific oligonucleotide probes for the N1303K mutation. (Lane 1) Positive control for heterozygosity of the N1303K mutation; (lanes 2-6) patient samples, all showing homozygosity for the normal allele; (lane 7) control representing a PCR reaction including all reagents except genomic DNA.

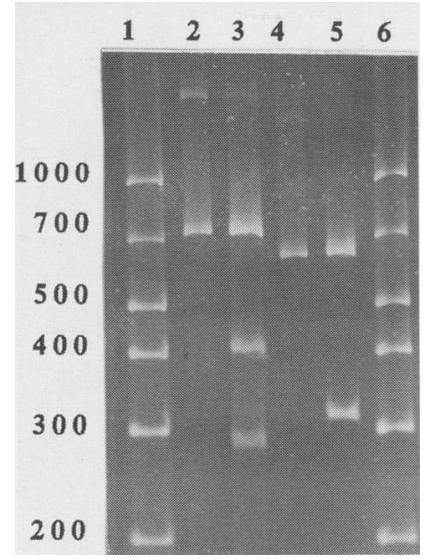

FIGURE 5 Acrylamide gel electrophoresis of patient samples assayed for XV2C/TaqI and KM19/PstI RFLPs. (Lanes 1 and 6) BioVentures molecular weight markers; (lane 2) XV2C PCR product; (lane 3) XV2C/TaqI; (lane 4) KM19 PCR product; (lane 5) KM19/PstI. presence of larger amounts of Taq polymerase inhibitors, such as hemoglobin. Therefore, we recommend the use of $1-\mathrm{mm}^{2}$ pieces in a $100-\mu \mathrm{l}$ PCR reaction to prevent such inhibitory effect. Chelex and spermidine were chosen because of their ability to improve the yield of PCR amplification reactions. ${ }^{(14)}$ Both were helpful, especially in the minority of samples $(\sim 5 \%)$ that were refractory to PCR amplification, even under optimum conditions of heating-cooling.

Use of direct PCR analysis of Guthrie blood spots offers significant advantages over other screening methods, including reduction of the time needed, therefore increasing the number of samples that could be handled conveniently. This approach may be automated, using direct automated sequencing by asymmetric $P C R,{ }^{(15)}$ and thereby increasing the feasibility of large-scale screening for CF.

\section{REFERENCES}

1. Saiki, R.K., D.H. Gelfard, S. Stoffel, S.J. Schart, R. Higuchi, G.T. Horn, K.B. Mullis, and H.A. Erlich. 1988. Primer directed enzymatic amplification of DNA with a thermostable DNA polymerase. Science 239: 487-491.

2. Mercier, B., C. Gaucher, O. Feugers, and C. Mazurier. 1990. Direct PCR from whole blood, without DNA extraction. Nucleic Acids Res. 18: 5908.

3. Kerem, B.S., J.M. Rommens, J.A. Buchanan, D. Markiewicz, T.K. Cox, A. Chakravarti, M. Buchwald, and L.C. Tsui. 1989. Identification of the cystic fibrosis gene: Genetic analysis. Science 245: 1073-1080.

4. Cutting, G.R., L.M. Kasc, B.J. Rosenstein, J. Zielenski, L.C. Tsui, S.E. Aontarakis, and
H.H. Kazazian, Jr. 1990. A cluster of cystic fibrosis mutations in the first nucleotidebinding fold of the CFTR. Nature 346: $366-368$.

5. Kerem, B.S., J. Zielenski, D. Markiewicz, D. Bozov, E. Gazit, J. Yahav, D. Kennedy, J.R. Riordan, and F.S. Collins. 1990. Identification of mutations in regions corresponding to the 2 putative nucleotide (ATP)-binding folds of the cystic fibrosis gene. Proc. Natl. Acad. Sci. 87: 8447-8451.

6. Osborne, L., R. Knight, G. Santis, and M. Hodson. 1991. A mutation in the second nucleotide binding fold of the cystic fibrosis gene. Am. J. Hum. Genet. 48: 608612.

7. Feldman, G.L., R. Williamson, A.L. Beaudet, and W.E. O'Brien. 1988. Prenatal diagnosis of cystic fibrosis by DNA ampiification for detection of KM-19 polymorphism. Lancet ii 102.

8. Rosenbloom, C.L., B.S. Kerem, J.M. Rommens, L.C. Tsui, B. Wainwright, R. Williamson, W.E. O'Brien, and E.A. Beaudet. 1989. DNA amplification for detection of the XV-2C polymorphism linked to cystic fibrosis. Nucleic Acids Res. 17: 7117 .

9. Williams, C., L. Weber, R. Williamson, and M. Hjelm. 1988. Guthrie spots for DNA-based carrier testing in cystic fibrosis. Lancet ii: 693.

10. Seltzer, W.K., F. Accurso, M.Z. Fall, A.J. Van Riper, M. Descartes, Y. Huang, and E. McCabe. 1991. Biochem. Med. Metabol. Bio. 46: 105-108.

11. Nelson, P.V., W.F. Carey, and C.P. Morris 1990. Gene amplification directly from Guthrie blood spots. Lancet 336: 14511452.

12. Schwartz, E.I., S.E. Khalchitsky, R.C. Eisensmith, and S.L.C. Woo. 1990. Polymerase chain reaction amplification from dried blood spots on Guthrie cards. Lancet 336: 639-640.

13. Chou, Q., M. Russell, D.E. Birch, J. Raymond, and W. Bloch. 1992. Prevention of pre-PCR mis-priming and primer dimerization improves low-copy-number amplifications. Nucleic Acids Res. 20: 17171723.

14. Walsh, P.S., D.A. Metzger, and R. Higuchi. 1991. Chelex 100 as a medium for simple extraction of DNA for PCR-based typing from forensic material. BioTechniques 10: $506-513$.

15. Descartes, M., Y. Huang, Y.H. Zhang, L.L. McCabe, R. Gibbs, B.L. Therrrel, and E.R.B. MaCabe. 1991. Genotyping confirmation from the original dried blood specimens in a neonatal hemoglobinopathy screening program. Pediatr. Res. 31: 217-221.

Received March 2, 1992; accepted in revised form June 15, 1992. 


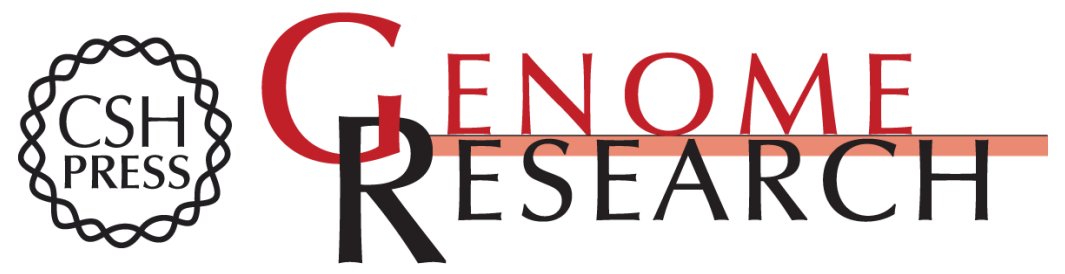

\section{Cystic fibrosis genotyping by direct PCR analysis of Guthrie blood spots.}

S Raskin, J A Phillips, G Kaplan, et al.

Genome Res. 1992 2: 154-156

Access the most recent version at doi:10.1101/gr.2.2.154

References This article cites 13 articles, 3 of which can be accessed free at:

http://genome.cshlp.org/content/2/2/154.full.html\#ref-list-1

\section{License}

Email Alerting Receive free email alerts when new articles cite this article - sign up in the box at the Service top right corner of the article or click here.

\section{Affordable, Accurate Sequencing.}

To subscribe to Genome Research go to: https://genome.cshlp.org/subscriptions 